\title{
Formation of Silver Nanoclusters from a DNA Template Containing Ag(I)-Mediated Base Pairs
}

\author{
J. Christian Léon, ${ }^{1}$ Linda Stegemann, ${ }^{2}$ Martin Peterlechner, ${ }^{3}$ Stefanie Litau, \\ Gerhard Wilde, ${ }^{3}$ Cristian A. Strassert, ${ }^{2}$ and Jens Müller ${ }^{1}$ \\ ${ }^{1}$ Westfälische Wilhelms-Universität Münster, Institut für Anorganische und Analytische Chemie, Corrensstraße 28/30, \\ 48149 Münster, Germany \\ ${ }^{2}$ Westfälische Wilhelms-Universität Münster, CeNTech, Physikalisches Institut, Heisenbergstraße 11, 48149 Münster, Germany \\ ${ }^{3}$ Westfälische Wilhelms-Universität Münster, Institut für Materialphysik, Wilhelm-Klemm-Straße 10, 48149 Münster, Germany
}

Correspondence should be addressed to Jens Müller; mueller.j@uni-muenster.de

Received 28 August 2015; Revised 22 December 2015; Accepted 27 December 2015

Academic Editor: Claudio Pettinari

Copyright (C) 2016 J. Christian Léon et al. This is an open access article distributed under the Creative Commons Attribution License, which permits unrestricted use, distribution, and reproduction in any medium, provided the original work is properly cited.

\begin{abstract}
A series of DNA double helices containing different numbers of silver(I)-mediated base pairs involving the artificial nucleobases imidazole or 2-methylimidazole has been applied for the generation of DNA-templated silver nanoclusters. The original Ag(I)containing nucleic acids as well as the resulting nanoclusters and nanoparticles have been characterized by means of UV/Vis spectroscopy, circular dichroism (CD) spectroscopy, fluorescence spectroscopy, and transmission electron microscopy (TEM). The results show for the first time that metal-mediated base pairs can be used for the templated growth of metal nanoclusters.
\end{abstract}

\section{Introduction}

Metal nanoclusters are a topical area of research due to their enormous applicability $[1,2]$. During the past years, the use of DNA-templated nanoclusters has drawn a lot of interest $[3,4]$. Depending on the experimental conditions, including the choice of appropriate oligonucleotide sequences, silver nanoclusters (AgNCs) of various sizes (and hence with diverse physical properties) can be obtained [5]. Even clusters as small as $\mathrm{Ag}_{3}$ or $\mathrm{Ag}_{2}$ have been synthesized [6]. In general, optical properties of the AgNCs appear to depend mainly on the cluster size, even though their interaction with DNA strongly affects these properties [5]. By choosing certain oligonucleotide sequences for the DNA-templated synthesis, distinct optical properties can be obtained [7-9]. First applications for DNA-templated AgNCs have been reported, too, including, for example, the detection of explosives [10]. Oligonucleotide sequences used for the templated synthesis of AgNCs often contain a large number of cytosine residues, probably as a result of the increased affinity of this canonical nucleobase for $\mathrm{Ag}(\mathrm{I})$ [11].
Within the last decade, the use of metal-mediated base pairs has been established as a versatile means for the sitespecific introduction of metal-based functionality into nucleic acids [12-16]. In these base pairs, the natural nucleobases (held together by hydrogen bonds) are formally replaced by artificial ones (held together by coordinate bonds to a central metal ion). $\mathrm{Ag}(\mathrm{I})$-mediated base pairs represent a prominent category of this novel type of base pairing. A few $\mathrm{Ag}(\mathrm{I})$-mediated base pairs comprising entirely natural bases are known, namely, cytosine-Ag(I)-cytosine [17-19], cytosine-Ag(I)-adenine [20], and cytosine-Ag(I)-thymine [21], giving a possible rationale for the above-mentioned tendency to use cytosine-rich oligonucleotides for the templated synthesis of AgNCs. Moreover, a variety of $\mathrm{Ag}(\mathrm{I})$-mediated base pairs with artificial nucleosides have been reported, for example, 1-deazaadenine-Ag(I)-thymine [22], pyridine$\mathrm{Ag}(\mathrm{I})$-pyridine [23], and base pairs with purine-derived ligands [24, 25]. Even dinuclear base pairs are known [2631]. The most prominent and best investigated artificial $\mathrm{Ag}(\mathrm{I})$-mediated base pairs contain imidazole nucleosides (Scheme 1) [32-37]. 


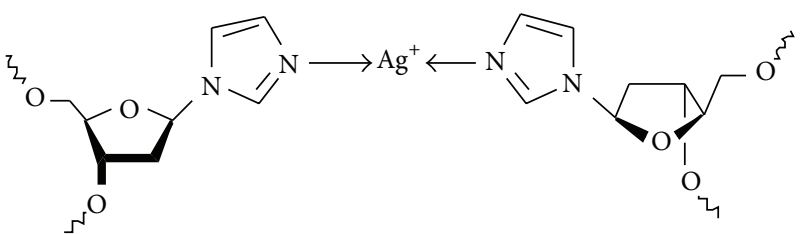

(a)

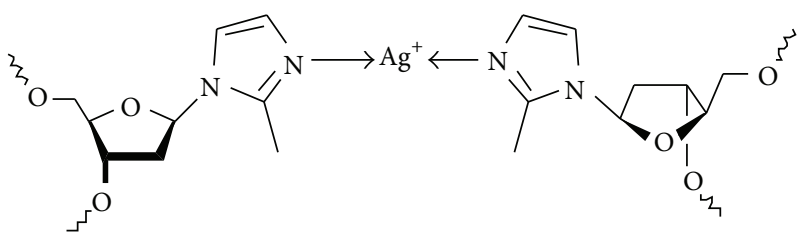

(b)

Scheme 1: Chemical structure of the $\operatorname{Ag}(\mathrm{I})$-mediated base pairs used in this study. (a) Imidazole-Ag(I)-imidazole; (b) 2-methylimidazole-Ag(I)-2-methylimidazole.

As was shown by means of an experimental NMR solution structure and its subsequent refinement by QM/MM methods $[33,34]$, the imidazole-Ag(I)-imidazole (Im-AgIm) base pair nicely fits into a regular B-DNA duplex without significantly distorting the nucleic acid backbone. Moreover, the affinity of an imidazole:imidazole mispair for an $\mathrm{Ag}(\mathrm{I})$ ion is about 10-fold higher than that of a cytosine:cytosine mispair [37]. Hence, we set out to investigate the use of Im-AgIm base pairs for the generation of DNA-templated AgNCs.

\section{Materials and Methods}

The artificial nucleosides were synthesized according to literature procedures $[33,35]$. Phosphoramidites of the canonical nucleosides were purchased from Glen Research. Oligonucleotide synthesis and purification were performed as previously reported [26]. Oligonucleotide concentrations were determined based on their absorbance. For the artificial nucleosides, a molar extinction coefficient $\varepsilon_{260}=$ $0.1 \mathrm{~cm}^{2} \mathrm{mmol}^{-1}$ was used. The desalted oligonucleotides were characterized by MALDI-TOF mass spectrometry (ODN1: calcd. for $[\mathrm{M}+\mathrm{H}]^{+}: 6498 \mathrm{Da}$, found: $6498 \mathrm{Da}$; ODN2: calcd. for $[\mathrm{M}+\mathrm{H}]^{+}$: $6464 \mathrm{Da}$, found: $6465 \mathrm{Da}$; ODN3: calcd. for $[\mathrm{M}+\mathrm{H}]^{+}: 6744 \mathrm{Da}$, found: $6745 \mathrm{Da}$; ODN4: calcd. for [M $+\mathrm{H}]^{+}: 6710 \mathrm{Da}$, found: $6712 \mathrm{Da}$; ODN5: calcd. for $[\mathrm{M}+$ $\mathrm{H}]^{+}$: $6554 \mathrm{Da}$, found: $6555 \mathrm{Da}$; ODN6: calcd. for $[\mathrm{M}+\mathrm{H}]^{+}$: $6520 \mathrm{Da}$, found: $6521 \mathrm{Da}$; ODN7: calcd. for $[\mathrm{M}+\mathrm{H}]^{+}: 6814 \mathrm{Da}$, found: $6814 \mathrm{Da}$; ODN8: calcd. for $[\mathrm{M}+\mathrm{H}]^{+}: 6780 \mathrm{Da}$, found: 6780 Da; ODN9: calcd. for $[\mathrm{M}+\mathrm{H}]^{+}: 5514 \mathrm{Da}$, found: $5512 \mathrm{Da}$; ODN10: calcd. for $[\mathrm{M}+\mathrm{H}]^{+}: 5481 \mathrm{Da}$, found: $\left.5477 \mathrm{Da}\right)$. MALDI-TOF mass spectra were recorded on a Bruker Reflex IV instrument using a 3-hydroxypicolinic acid/ammonium citrate matrix. Temperature-dependent UV measurements were performed on a UV spectrometer CARY 100 Bio instrument. UV melting curves were recorded from 10 to $80^{\circ} \mathrm{C}$ using solutions containing $2 \mu \mathrm{M}$ oligonucleotide duplex, $150 \mathrm{mM} \mathrm{NaClO}_{4}, 5 \mathrm{mM}$ MOPS (pH 6.8), and an appropriate amount of $\mathrm{AgNO}_{3}$ with a heating/cooling rate of $1^{\circ} \mathrm{C} \mathrm{min}{ }^{-1}$ and a data interval of $0.5^{\circ} \mathrm{C}$. Absorbance was normalized according to $A_{\text {norm }}=\left(A-A_{\min }\right) /\left(A_{\max }-A_{\min }\right)$ at $260 \mathrm{~nm}$. Melting temperatures were determined from the maxima of the first derivatives of the melting curves. Reduction of the metal-mediated base pairs was performed at ambient temperature by adding a freshly prepared aqueous solution of $\mathrm{NaBH}_{4}$ to a solution containing $40 \mu \mathrm{M}$ oligonucleotide duplex (in $150 \mathrm{mM} \mathrm{NaClO}_{4}$, one equivalent of $\mathrm{AgNO}_{3}$, and $5 \mathrm{mM} \mathrm{MOPS}$ ( $\mathrm{pH}$ 6.8)) that had previously been heated to $65^{\circ} \mathrm{C}$ and then cooled to $10^{\circ} \mathrm{C}$ at a rate of $1^{\circ} \mathrm{C} \mathrm{min}^{-1}$. In the case of duplex $\mathrm{V}$ and the nucleic-acid-free reference measurement, $160 \mu \mathrm{M}$ $\mathrm{AgNO}_{3}$ was used in the same aqueous buffer. UV/Vis spectra of the reduced solutions were recorded on a Nanodrop 2000c instrument. They were normalized with respect to a $1 \mathrm{~cm}$ path length (assuming $\varepsilon_{260}=332 \mathrm{~cm}^{2} \mu \mathrm{mol}^{-1}$ for oligonucleotide duplexes I-IV and $\varepsilon_{260}=424 \mathrm{~cm}^{2} \mu \mathrm{mol}^{-1}$ for duplex V) and smoothed. For the nucleic-acid-free solution, a scaling factor of 18 (similar to the ones calculated for duplexes I, III, and $\mathbf{V}$ with the same $\mathrm{Ag}(\mathrm{I})$ concentration as the nucleic-acidfree solution) was applied. CD spectra were recorded at $10^{\circ} \mathrm{C}$ on a JASCO J-815 spectropolarimeter, and a manual baseline correction was applied. The TEM measurements were carried out on a Libra 200 FE TEM (Zeiss) equipped with a field emission gun operating at $200 \mathrm{kV}$, an in-column energy filter, a Noran energy dispersive X-ray (EDX) detector, and a Gatan US4000 CCD. Conventional TEM data were recorded using an energy filter window size of $30 \mathrm{eV}$ symmetrically around the zero loss. TEM samples were obtained using $\mathrm{Cu}$-grids with a holey carbon film by slewing the grids in the solutions. Steady-state emission spectra were recorded on a FluoTime300 spectrometer from PicoQuant equipped with a $300 \mathrm{~W}$ ozone-free Xe lamp (250-900 nm), an excitation monochromator (Czerny-Turner $2.7 \mathrm{~nm} \mathrm{~mm}^{-1}$ dispersion, 1200 grooves $\mathrm{mm}^{-1}$, blazed at $300 \mathrm{~nm}$ ), two emission monochromators (Czerny-Turner, selectable gratings blazed at $500 \mathrm{~nm}$ with $2.7 \mathrm{~nm} \mathrm{~mm}^{-1}$ dispersion and 1200 grooves $\mathrm{mm}^{-1}$, or blazed at $1250 \mathrm{~nm}$ with $5.4 \mathrm{~nm} \mathrm{~mm}^{-1}$ dispersion and 600 grooves $\mathrm{mm}^{-1}$ ), and a PMA Hybrid 40 (transit time spread FWHM $<120$ ps, 300-720 nm). Emission spectra were corrected for source intensity (lamp and grating) by standard correction curves.

\section{Results and Discussion}

3.1. Characterization of the Ag(I)-Binding Behavior of the Oligonucleotides. Five slightly different nucleic acid duplexes were investigated with respect to their capability to act as templates for the formation of AgNCs. Table 1 gives an overview of the sequences. Duplexes I and III comprise four designated Ag(I)-binding sites, duplexes II and IV five designed Ag(I)-binding sites. The artificial nucleobases used to generate the binding sites are imidazole (duplexes I and II) and 2-methylimidazole (duplexes III and IV). The latter constitutes a 2nd generation imidazole-type nucleobase with an increased thermal stability of the resulting $\mathrm{Ag}(\mathrm{I})$-mediated base pair, in which for steric reasons the central $\mathrm{Ag}(\mathrm{I})$ ion is expected to have a smaller solvent accessibility [35]. Duplex $\mathbf{V}$ serves are a reference duplex without any artificial nucleobases. 
TABLE 1: DNA oligonucleotide duplexes and sequences investigated in this study.

\begin{tabular}{llc}
\hline Duplex & Sequence $^{\mathrm{a}}$ & Sequence number \\
\hline I & $5^{\prime}-\mathrm{d}($ GTT TGT TTG XXX XTG TTT TTT T) & ODN1 \\
& $3^{\prime}-\mathrm{d}($ CAA ACA AAC XXX XAC AAA AAA A) & ODN2 \\
\hline \multirow{2}{*}{ II } & $5^{\prime}-\mathrm{d}($ GTT TGT TTG XXX XXT GTT TTT TT) & ODN3 \\
& $3^{\prime}-\mathrm{d}($ CAA ACA AAC XXX XXA CAA AAA AA) & ODN4 \\
\hline \multirow{2}{*}{ III } & $5^{\prime}-\mathrm{d}($ GTT TGT TTG YYY YTG TTT TTT T) & ODN5 \\
& $3^{\prime}-\mathrm{d}($ CAA ACA AAC YYY YAC AAA AAA A) & ODN6 \\
\hline IV & $5^{\prime}-\mathrm{d}($ GTT TGT TTG YYY YYT GTT TTT TT) & ODN7 \\
\hline $\mathbf{V}$ & $3^{\prime}-\mathrm{d}($ CAA ACA AAC YYY YYA CAA AAA AA) & ODN8 \\
\hline & $5^{\prime}-\mathrm{d}($ GTT TGT TTG TGT TTT GTT TTT TT) & ODN9 \\
\hline
\end{tabular}

${ }^{a} \mathbf{X}=$ imidazole nucleoside, $\mathbf{Y}=$ 2-methylimidazole nucleoside.

To ensure that indeed distinct $\mathrm{Ag}(\mathrm{I})$-mediated base pairs are formed, melting curves of the duplexes were determined by temperature-dependent UV spectroscopy in the presence of increasing amounts of $\mathrm{Ag}(\mathrm{I})$. During the following discussion, one equivalent of $\mathrm{Ag}(\mathrm{I})$ is defined as the amount of $\mathrm{Ag}(\mathrm{I})$ required for the formation of all possible $\mathrm{Ag}(\mathrm{I})$-mediated base pairs. Hence, for duplexes I and III one equivalent equals four $\mathrm{Ag}(\mathrm{I})$ ions, whereas for duplexes II and IV one equivalent equals five $\operatorname{Ag}(\mathrm{I})$ ions. This definition allows the discussion of the different duplexes irrespective of their absolute $\mathrm{Ag}(\mathrm{I})$ content.

As can be seen from the melting curves shown in Figure 1, the addition of $\operatorname{Ag}(\mathrm{I})$ leads to a large thermal stabilization. Interestingly, the addition of excess $\mathrm{Ag}(\mathrm{I})$ results in a rather small additional increase of the melting temperature $T_{m}$. This behavior (large increase in $T_{m}$ upon the addition of one equivalent of $\operatorname{Ag}(\mathrm{I})$, much smaller increase thereafter) is typical for the formation of metal-mediated base pairs [12]. It indicates that the artificial mispairs indeed represent the highest-affinity binding sites for $\mathrm{Ag}(\mathrm{I})$. This is confirmed by a reference measurement using duplex $\mathbf{V}$ without any artificial nucleosides. The addition of $\mathrm{Ag}(\mathrm{I})$ to duplex $\mathbf{V}$ leads to an increase in $T_{m}$ of a little more than $1^{\circ} \mathrm{C}$ per $\mathrm{Ag}(\mathrm{I})$ only $\left(\Delta T_{m}=6^{\circ} \mathrm{C}\right.$ for four $\left.\mathrm{Ag}(\mathrm{I})\right)$. For duplexes I-IV, additional $\mathrm{Ag}(\mathrm{I})$ probably binds nonspecifically to the negatively charged nucleic acid backbone [38] or to vacant sites on the canonical nucleobases [39]. Table 2 lists the melting curves of the duplexes in the absence and presence of one equivalent of $\operatorname{Ag}(\mathrm{I})$, that is, with and without $\operatorname{Ag}(\mathrm{I})$-mediated base pairs. As expected, the use of 2-methylimidazole leads to the formation of thermally more stable $\mathrm{Ag}(\mathrm{I})$-mediated base pairs. The average stabilization per individual $\mathrm{Ag}(\mathrm{I})$ mediated base pairs amounts to $5-6^{\circ} \mathrm{C}$.

Circular dichroism (CD) spectroscopy was performed to elucidate the conformations of the $\mathrm{Ag}(\mathrm{I})$-free and the $\mathrm{Ag}(\mathrm{I})$ containing nucleic acid duplexes. As can be seen from the CD spectra shown in Figure 2, the addition of $\mathrm{Ag}(\mathrm{I})$ does not induce significant conformational changes to the duplexes. Minor changes are seen in the CD spectrum of duplex II, which is not unexpected, because it contains the largest number of mispairs among the investigated duplexes that
TABLE 2: Melting temperatures $T_{m} /{ }^{\circ} \mathrm{C}$ of the duplexes in the absence and presence of $\operatorname{Ag}(\mathrm{I})^{\mathrm{a}}$.

\begin{tabular}{lccc}
\hline & $\begin{array}{c}\text { 0 equivalent } \\
\text { of } \mathrm{Ag}(\mathrm{I})\end{array}$ & $\begin{array}{c}1 \text { equivalent } \\
\text { of } \mathrm{Ag}(\mathrm{I})\end{array}$ & $\begin{array}{c}\Delta T_{m}(0 \rightarrow 1 \\
\text { equivalent of } \\
\mathrm{Ag}(\mathrm{I}))\end{array}$ \\
\hline Duplex I & 30.6 & 51.1 & 20.5 \\
Duplex II & 29.5 & 52.2 & 22.7 \\
Duplex III & 32.8 & 60.8 & 28.0 \\
Duplex IV & 30.7 & 60.7 & 30.0 \\
Duplex V & 52.4 & $58.4^{\mathrm{b}}$ & $6.0^{\mathrm{b}}$ \\
\hline
\end{tabular}

${ }^{\mathrm{a} C o n d i t i o n s: ~} 2 \mu \mathrm{M}$ duplex, $150 \mathrm{mM} \mathrm{NaClO}_{4}$, and $5 \mathrm{mM}$ MOPS (pH 6.8).

${ }^{\mathrm{b}}$ Four $\mathrm{Ag}(\mathrm{I})$ were added to the duplex.

become metal-mediated base pairs in the presence of $\mathrm{Ag}(\mathrm{I})$. Importantly, the $\mathrm{CD}$ spectrum of the native DNA duplex $\mathbf{V}$ in the presence of increasing amounts of $\mathrm{Ag}(\mathrm{I})$ shows a decrease in molar ellipticity at around $270 \mathrm{~nm}$. A similar change becomes evident in the CD spectra of duplexes I and II only if more than one equivalent of $\mathrm{Ag}(\mathrm{I})$ is present, thereby confirming that the imidazole-based mispairs represent the highest-affinity binding sites for $\mathrm{Ag}(\mathrm{I})$. In general, the $\mathrm{CD}$ spectra resemble those of duplexes rich in adenine:thymine base pairs consisting of one purine-rich and one pyrimidinerich strand [40].

3.2. Spectroscopic Properties of the DNA-Templated Ag Nanoclusters. Reduction of the $\mathrm{Ag}(\mathrm{I})$ ions to give AgNCs was achieved by the addition of an excess of a freshly prepared aqueous solution of $\mathrm{NaBH}_{4}$. Contrary to the experiments described in Section 3.1, duplex concentrations of $40 \mu \mathrm{M}$ were used. A uniform formation of oligonucleotide duplexes with $\mathrm{Ag}(\mathrm{I})$-mediated base pairs was achieved by heating buffered aqueous solutions of the duplexes to $65^{\circ} \mathrm{C}$ and slowly cooling them to $10^{\circ} \mathrm{C}$ in the presence of one equivalent of $\mathrm{AgNO}_{3}$.

Upon reduction, the colorless oligonucleotide solutions turned yellowish brown. The UV/Vis spectra clearly indicate the presence of new absorbance maxima in the visible range 


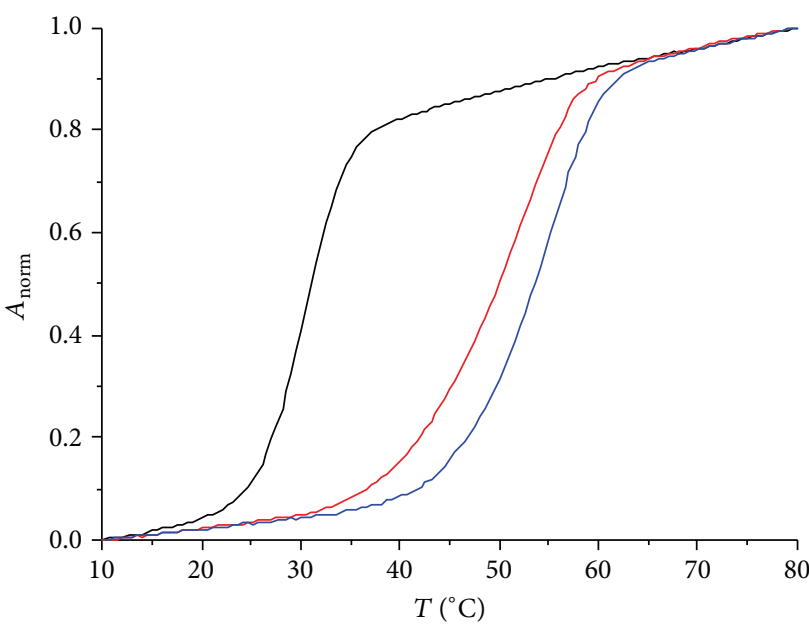

(a)

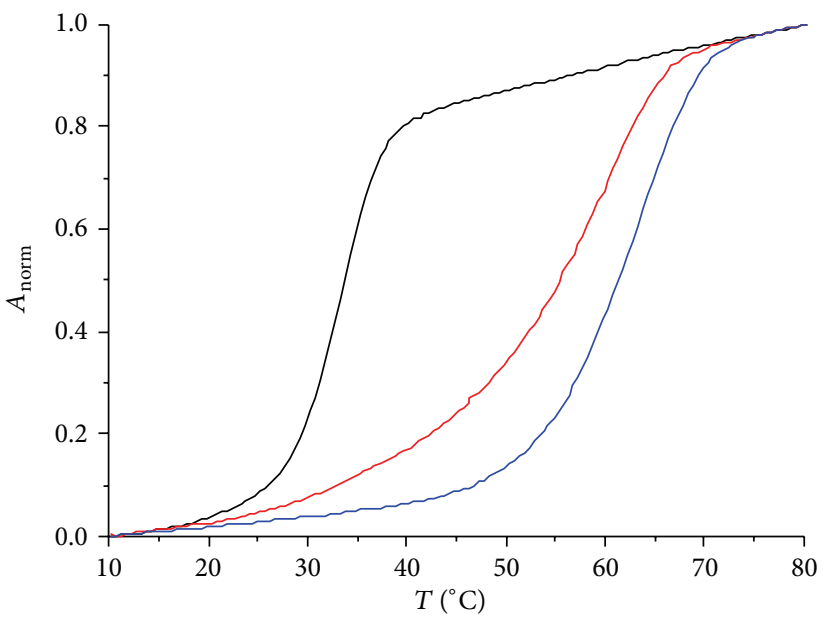

(c)

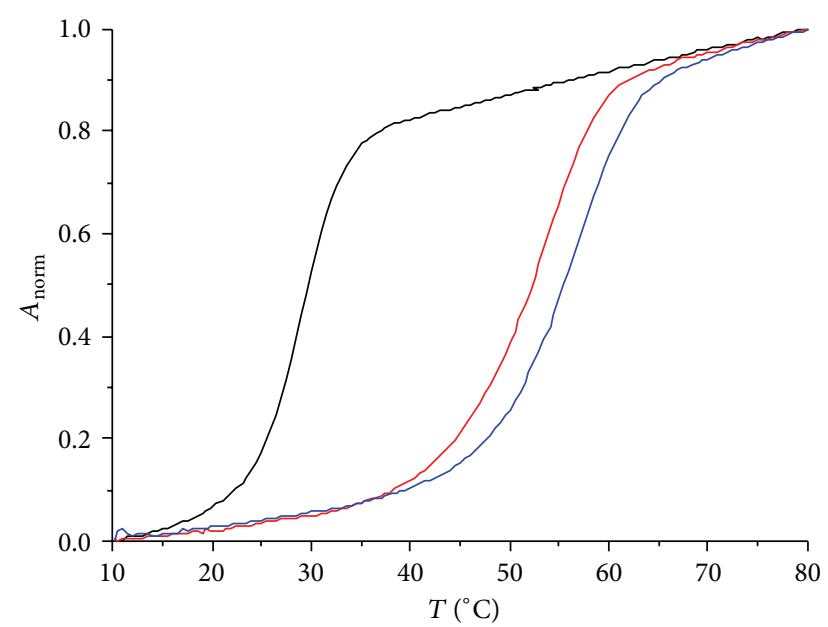

(b)

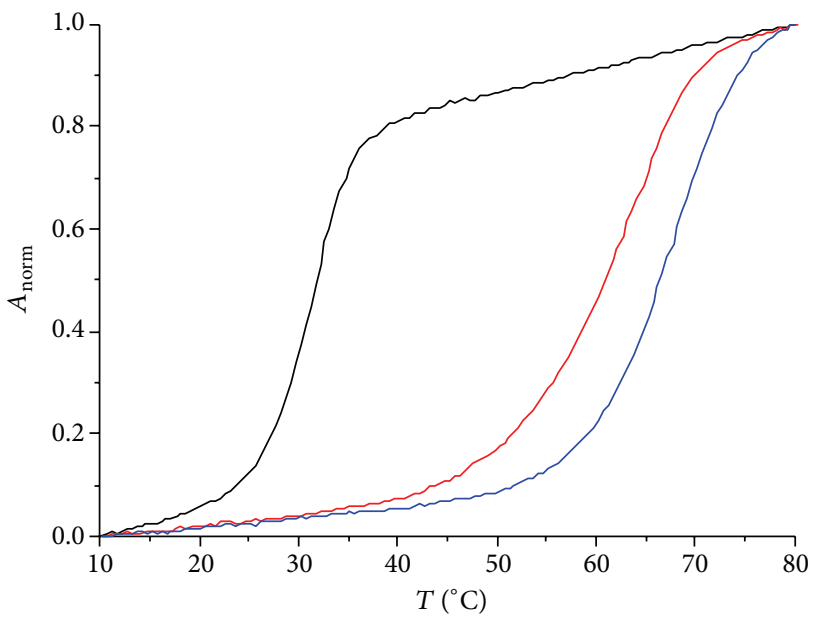

(d)

Figure 1: Melting curves of duplexes I-IV in the presence of various equivalents of $\operatorname{Ag}(\mathrm{I})$ (black: no $\mathrm{Ag}(\mathrm{I}) ; \operatorname{red}: 1$ equiv. of $\mathrm{Ag}(\mathrm{I})$; blue: 1.5 equiv. of $\mathrm{Ag}(\mathrm{I})$ ): (a) duplex I; (b) duplex II; (c) duplex III; (d) duplex IV.

TABLE 3: UV/Vis spectroscopic data of silver nanoparticles and nanoclusters formed upon reduction of Ag(I)-containing duplexes I-V . $^{\mathrm{a}}$

\begin{tabular}{|c|c|c|c|c|c|}
\hline & Duplex I & Duplex II & Duplex III & Duplex IV & Duplex V \\
\hline$\lambda_{\max } / \mathrm{nm}$ & 393,582 & $394,495,577$ & 389 & $406,494,571$ & 394 \\
\hline
\end{tabular}

(Figure 3). In particular, a new peak at $\sim 395 \mathrm{~nm}$ is observed for all four imidazole-comprising duplexes as well as for the native DNA duplex. An additional peak at $\sim 575 \mathrm{~nm}$ can be found in the spectra of duplexes II and IV and to a smaller extent also in the spectrum of duplex I. The spectra of duplexes II and IV also feature smaller peaks around $\sim 495 \mathrm{~nm}$. Table 3 lists the UV/Vis spectroscopic data of duplexes $\mathbf{I}-\mathbf{V}$ after the addition of $\mathrm{NaBH}_{4}$. The peak around 395-405 $\mathrm{nm}$ indicates the formation of silver nanoparticles with a diameter of $10-14 \mathrm{~nm}$ [41]. With time, this peak becomes broader and red-shifted, indicating a further aggregation of the nanoparticles [41]. In contrast, the additional peak at $\sim 575 \mathrm{~nm}$ has previously been associated with the formation of nanoclusters [42] and hence indicates that the anticipated AgNCs were formed as well. It is interesting to note that the reduction of $\mathrm{AgNO}_{3}$ by $\mathrm{NaBH}_{4}$ in the absence of any DNA does not lead to a colored solution (Figure 3, orange spectrum), indicating the absence of small silver nanoparticles or nanoclusters. Moreover, the reduction of $\mathrm{AgNO}_{3}$ in the presence of the native duplex $\mathbf{V}$ does not lead to species with an absorbance maximum above $500 \mathrm{~nm}$.

As AgNCs are well-known for their fluorescent properties [1], the reduced nucleic acid solutions of duplexes I and II were subjected to fluorescence spectroscopic characterization. As indicated by Figure 4, no significant fluorescence signal was detected upon the reduction of the $\mathrm{Ag}(\mathrm{I})$-containing 


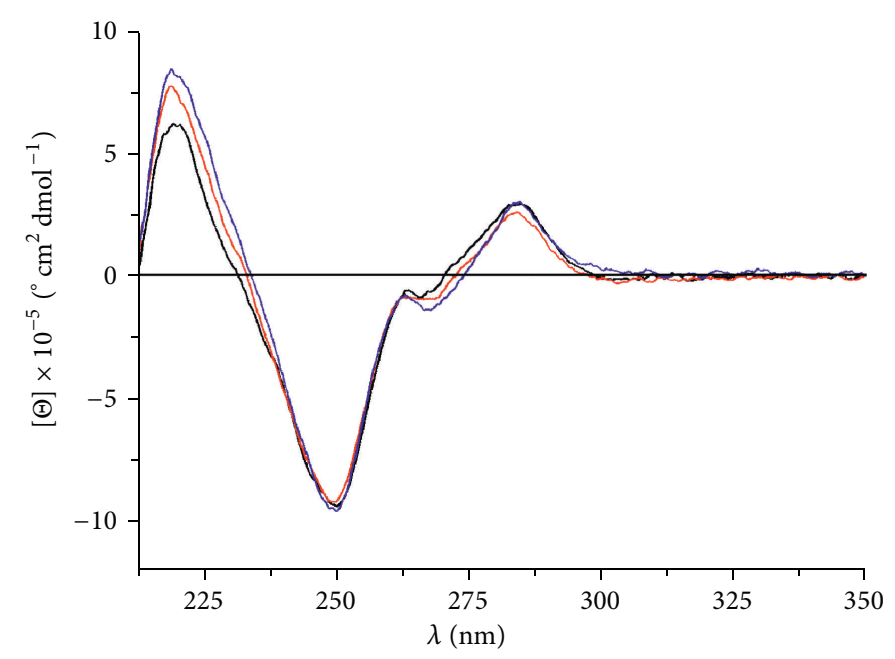

(a)

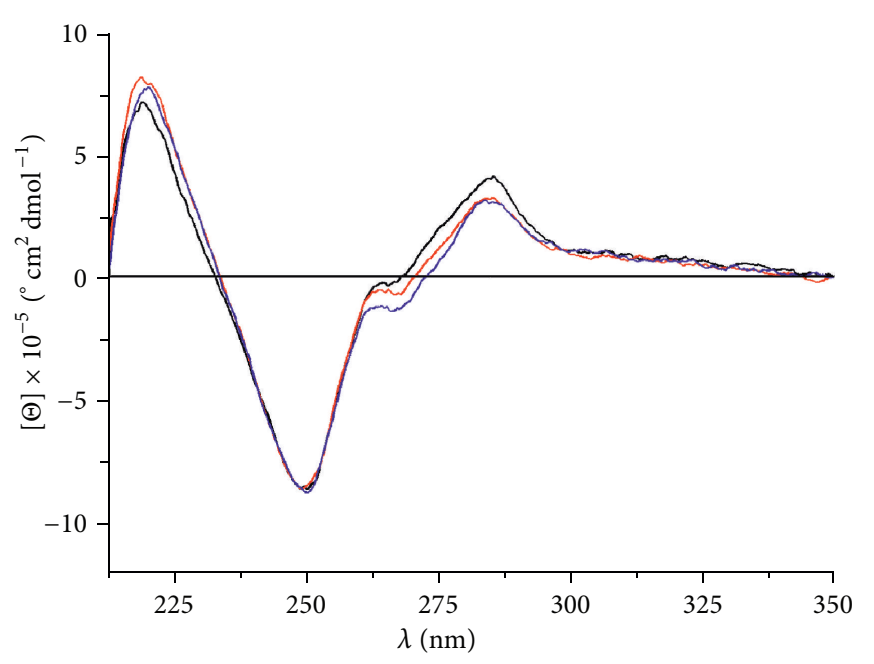

(b)

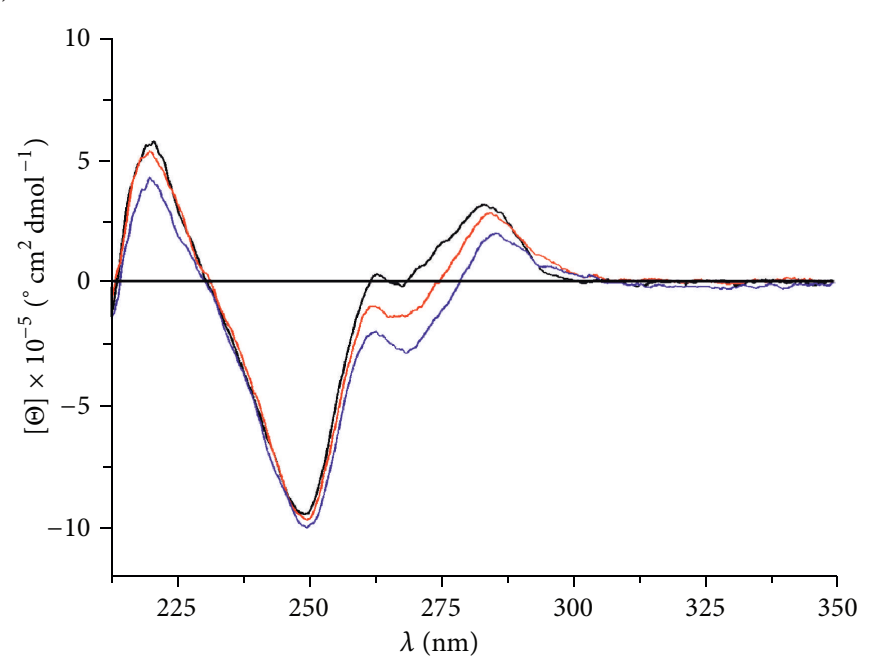

(c)

Figure 2: CD spectra of (a) duplex I, (b) duplex II, and (c) duplex V in the absence or presence of $\mathrm{Ag}(\mathrm{I})$ (black: no $\mathrm{Ag}(\mathrm{I})$; red: 1 equiv. of $\mathrm{Ag}(\mathrm{I})$; blue: 1.5 equiv. of $\mathrm{Ag}(\mathrm{I}))$. The CD spectra of duplexes III and IV including 2-methylimidazole rather than imidazole are essentially the same $[35,37]$ and are therefore not shown. In (c), a different color code applies (red: 4 Ag(I) per duplex; blue: 6 Ag(I) per duplex).

oligonucleotide duplexes. The marginal fluorescence around $400-550 \mathrm{~nm}$ observed both prior to and after the reduction can most likely be attributed to the intrinsic fluorescence of DNA, as was shown by recording fluorescence spectra also in the absence of any $\mathrm{Ag}(\mathrm{I})$ and of any AgNCs. The lack of fluorescence may be explained by the use of a doublestranded DNA template, as duplex DNA has previously been shown to produce AgNCs with negligible visible fluorescence [7]. It has been suggested that this may be due to electronic configurations without excitations in the visible range and/or excitations that decay rapidly in a nonradiative manner [7].

3.3. TEM Measurements. To investigate whether, despite the lack of significant fluorescence, AgNCs have been obtained, TEM measurements were performed for the reduced solutions of duplexes I, II, and V. The resulting images confirm that nanoparticles ( $>10 \mathrm{~nm}$ diameter) and nanoclusters
$(<10 \mathrm{~nm}$ diameter) are formed. EDX spectroscopy confirms the particles to be composed of silver. In agreement with that, diffraction experiments combined with dark-/brightfield imaging shows single crystalline silver particles. Figure 5 shows selected TEM images devoid of larger aggregates. As can be seen, the particle diameter in these sections is mostly in the order of $2 \mathrm{~nm}-10 \mathrm{~nm}$. The particles are basically spherical. The existence of additional nanoclusters smaller than $2 \mathrm{~nm}$ cannot be ruled out, as these are below the resolution of the present TEM experiments using holey carbon grids. The average size of the nanoclusters obtained from duplex II (with 2-methylimidazole) shown in Figure 5 is within standard error identical $(d=5 \pm 2 \mathrm{~nm}, N=111)$ to the size of those obtained from duplex I (with imidazole) ( $d=4 \pm 2 \mathrm{~nm}, N=118$ ). Hence, there seems to be no simple correlation between the number of $\mathrm{Ag}(\mathrm{I})$-mediated base pairs and the size distribution of the resulting AgNCs. 


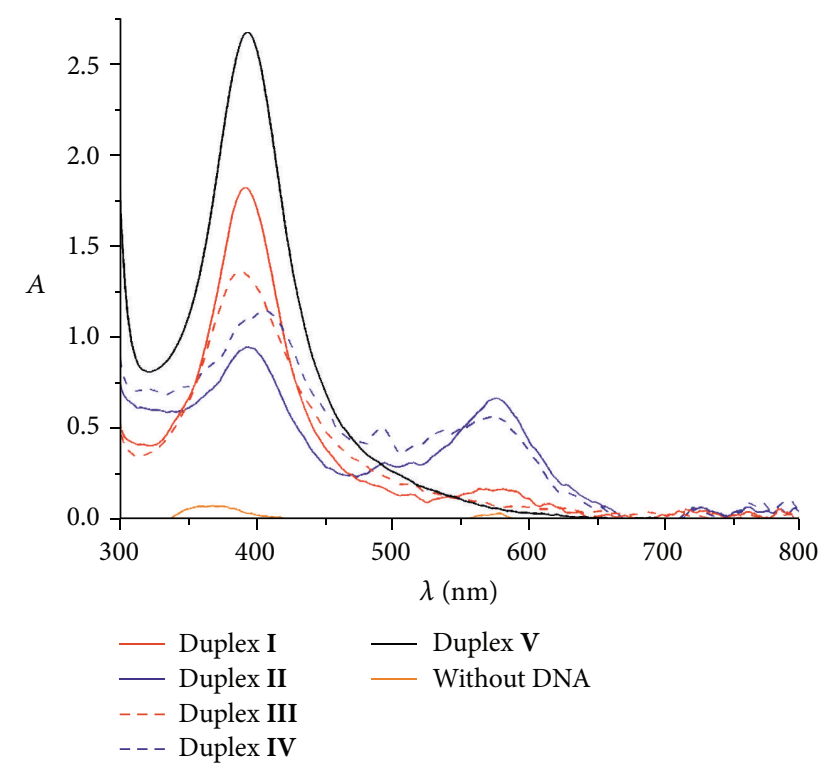

FIGURE 3: Section of the UV/Vis spectra of duplexes I-V after the reduction by $\mathrm{NaBH}_{4}$. In the absence of DNA, practically no absorbance is detected.

For the native DNA duplex $\mathbf{V}$, a much wider size distribution was observed (Figure 5(c), $d=6 \pm 4 \mathrm{~nm}, N=107$ ). In general, the silver nanoparticles tend to be a bit larger than those obtained from DNA with $\mathrm{Ag}(\mathrm{I})$-mediated base pairs. Finally, the reduction of an identical concentration of $\mathrm{Ag}(\mathrm{I})$ in the absence of DNA led to a completely different appearance of the resulting silver (Figure 5(d)). Individual spherical nanoparticles or nanoclusters were either not formed or not stable in this case, as only aggregates were observed. Hence, the TEM measurements show that the nucleic acids with $\mathrm{Ag}(\mathrm{I})$ mediated base pairs give the smallest AgNCs with the most narrow size distribution.

\section{Conclusions}

This study shows for the first time that nucleic acids with artificial $A g(\mathrm{I})$-mediated base pairs can be applied for the generation of silver nanoclusters. Formation of the clusters was confirmed by TEM. Despite the fact that the nucleic acids contain a discrete number of $\mathrm{Ag}(\mathrm{I})$ ions per duplex, the AgNCs were not found to be monodisperse. Nonetheless, a much more narrow size distribution was observed compared with an entirely natural DNA duplex template, indicating the relevance of the $\mathrm{Ag}(\mathrm{I})$-mediated base pairs for cluster formation. Moreover, the nanoclusters formed from DNA with $\mathrm{Ag}(\mathrm{I})$-mediated base pairs have different spectroscopic properties compared with those formed from native DNA in the presence of $\mathrm{AgNO}_{3}$, as evident from the absorbance maxima in their UV/Vis spectra. The initially formed small nanoclusters have a tendency to aggregate in the case of duplexes I-IV. Such a time-dependent growth of nanoparticles was followed UV/Vis-spectroscopically. Considering that numerous metal-mediated base pairs have been established for a range of different metal ions, this study opens a new and

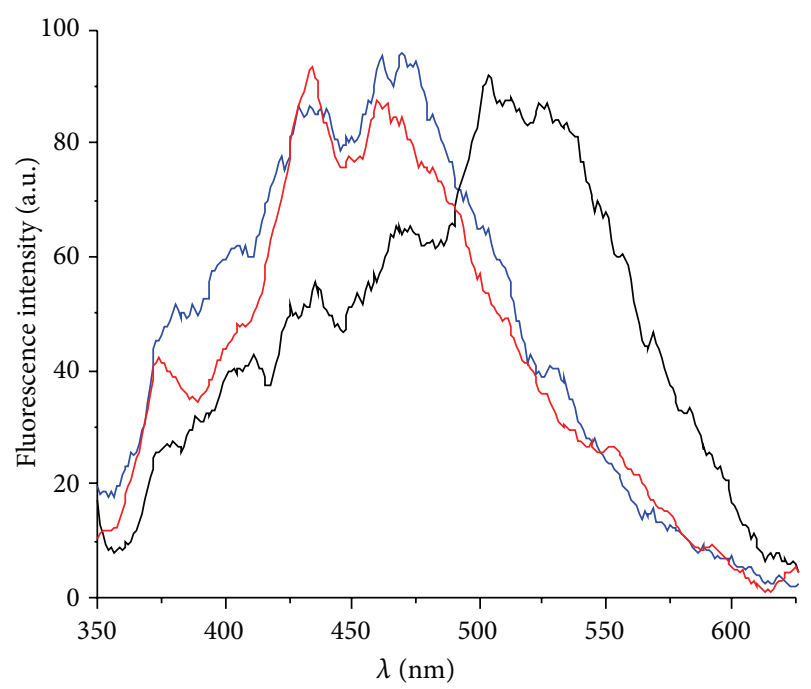

(a)

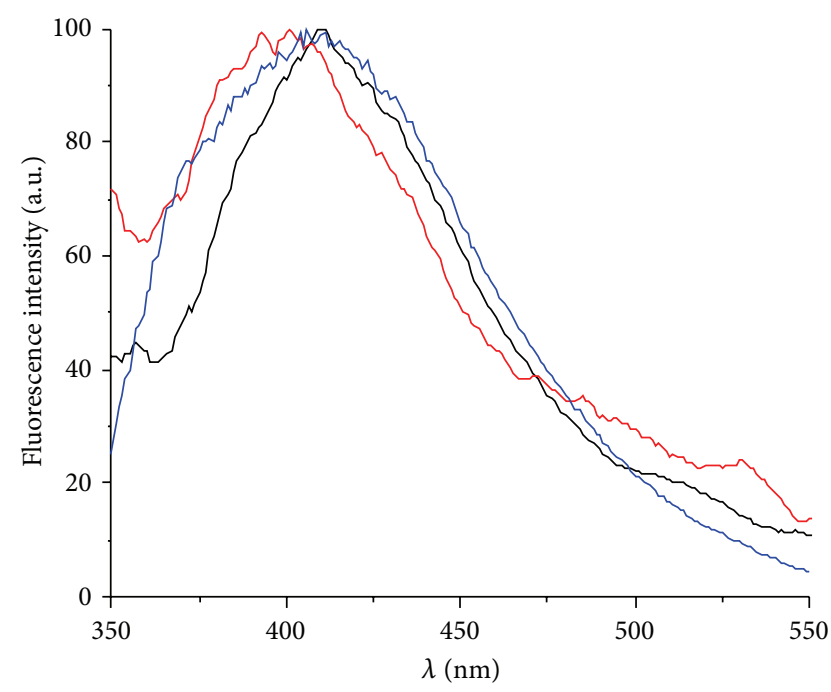

(b)

Figure 4: Fluorescence spectra of (a) duplex I and (b) duplex II upon excitation at $330 \mathrm{~nm}$ (blue: in the absence of $\mathrm{Ag}(\mathrm{I})$; black: in the presence of 1 equiv. of $\mathrm{Ag}(\mathrm{I})$; red: after reduction by $\left.\mathrm{NaBH}_{4}\right)$. The weak intensity indicates that the samples are essentially nonfluorescent.

promising avenue towards the formation of nanoclusters of different metals. Depending on the identity of the metal ion included in the metal-mediated base pair, different nanoclusters with distinct physical properties should be obtainable.

\section{Conflict of Interests}

The authors declare that there is no conflict of interests regarding the publication of this paper.

\section{Acknowledgments}

Financial support by the Deutsche Forschungsgemeinschaft (TRR 61, Project C07) is gratefully acknowledged. The 

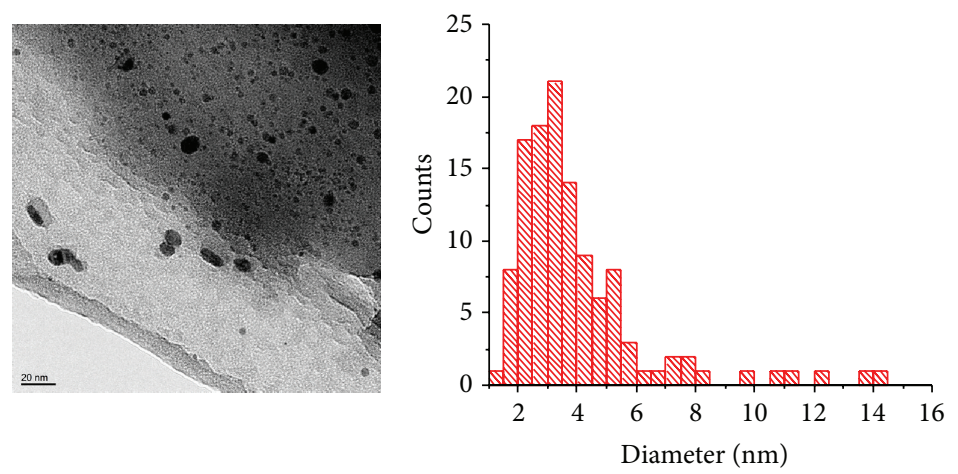

(a)
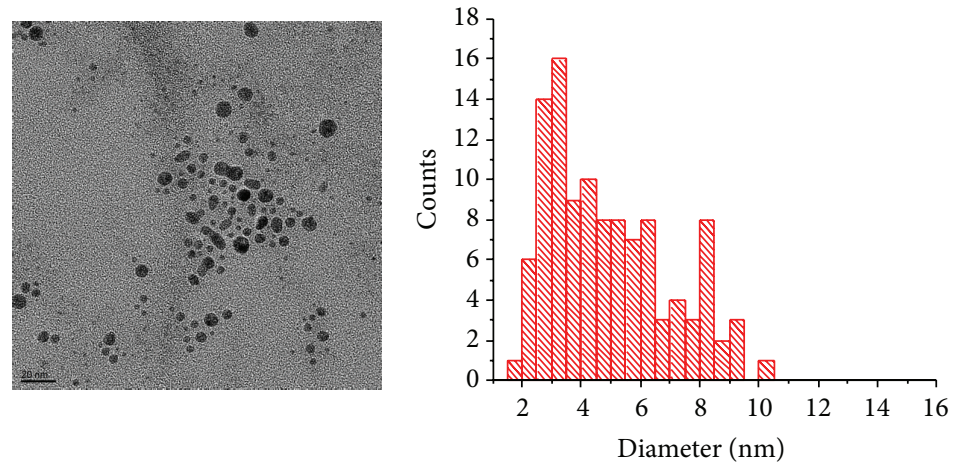

(b)
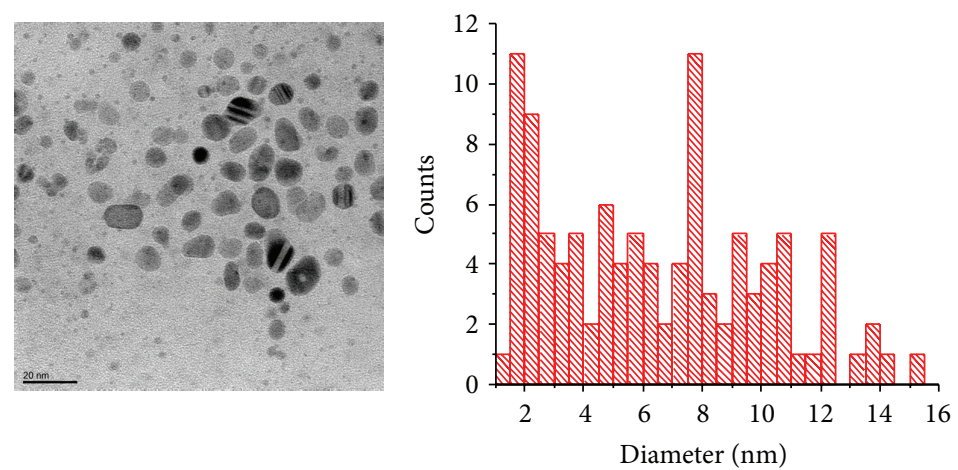

(c)

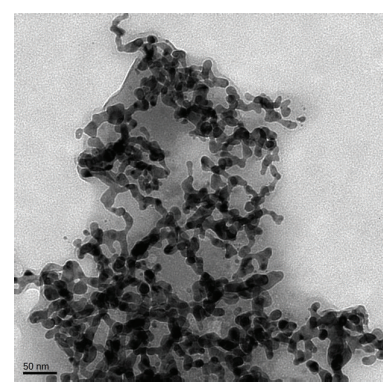

(d)

FIGURE 5: TEM bright-field images of silver nanoclusters and nanoparticles on a carbon film. Solutions of (a) duplex I, (b) duplex II, (c) duplex $\mathbf{V}$, and (d) without nucleic acid in the presence of $\mathrm{AgNO}_{3}$ after the reduction with $\mathrm{NaBH}_{4}$ led to the shown images and corresponding histograms of the size distribution. Please note the different scale bars in (c) and (d). 
authors thank Dr. Anzhela Galstyan for recording some of the fluorescence spectra.

\section{References}

[1] I. Díez and R. H. A. Ras, "Fluorescent silver nanoclusters," Nanoscale, vol. 3, no. 5, pp. 1963-1970, 2011.

[2] L. Shang, S. Dong, and G. U. Nienhaus, "Ultra-small fluorescent metal nanoclusters: synthesis and biological applications," Nano Today, vol. 6, no. 4, pp. 401-418, 2011.

[3] J. T. Petty, J. Zheng, N. V. Hud, and R. M. Dickson, "DNAtemplated Ag nanocluster formation," Journal of the American Chemical Society, vol. 126, no. 16, pp. 5207-5212, 2004.

[4] S. M. Copp, D. E. Schultz, S. Swasey, and E. G. Gwinn, "Atomically precise arrays of fluorescent silver clusters: a modular approach for metal cluster photonics on DNA nanostructures," ACS Nano, vol. 9, no. 3, pp. 2303-2310, 2015.

[5] J. T. Petty, S. P. Story, J.-C. Hsiang, and R. M. Dickson, "DNAtemplated molecular silver fluorophores," Journal of Physical Chemistry Letters, vol. 4, no. 7, pp. 1148-1155, 2013.

[6] D. Buceta, N. Busto, G. Barone et al., " $\mathrm{Ag}_{2}$ and $\mathrm{Ag}_{3}$ clusters: synthesis, characterization, and interaction with DNA," Angewandte Chemie-International Edition, vol. 54, no. 26, pp. 76127616, 2015.

[7] E. G. Gwinn, P. O’Neill, A. J. Guerrero, D. Bouwmeester, and D. K. Fygenson, "Sequence-dependent fluorescence of DNAhosted silver nanoclusters," Advanced Materials, vol. 20, no. 2, pp. 279-283, 2008.

[8] Y. Teng, X. Yang, L. Han, and E. Wang, “The relationship between DNA sequences and oligonucleotide-templated silver nanoclusters and their fluorescence properties," Chemistry $-A$ European Journal, vol. 20, no. 4, pp. 1111-1115, 2014.

[9] A. Latorre, R. Lorca, F. Zamora, and Á. Somoza, "Enhanced fluorescence of silver nanoclusters stabilized with branched oligonucleotides," Chemical Communications, vol. 49, no. 43, pp. 4950-4952, 2013.

[10] N. Enkin, E. Sharon, E. Golub, and I. Willner, "Ag nanocluster/DNA hybrids: functional modules for the detection of nitroaromatic and RDX explosives," Nano Letters, vol. 14, no. 8, pp. 4918-4922, 2014.

[11] L. Liu, Q. Yang, J. Lei, N. Xu, and H. Ju, "DNA-regulated silver nanoclusters for label-free ratiometric fluorescence detection of DNA," Chemical Communications, vol. 50, no. 89, pp. 1369813701, 2014.

[12] J. Müller, "Metal-ion-mediated base pairs in nucleic acids," European Journal of Inorganic Chemistry, no. 24, pp. 3749-3763, 2008.

[13] P. Scharf and J. Müller, "Nucleic acids with metal-mediated base pairs and their applications," ChemPlusChem, vol. 78, no. 1, pp. 20-34, 2013.

[14] Y. Takezawa and M. Shionoya, "Metal-mediated DNA base pairing: alternatives to hydrogen-bonded Watson-Crick base pairs," Accounts of Chemical Research, vol. 45, no. 12, pp. 20662076, 2012.

[15] G. H. Clever, C. Kaul, and T. Carell, "DNA-metal base pairs," Angewandte Chemie - International Edition, vol. 46, no. 33, pp. 6226-6236, 2007.

[16] A. Ono, H. Torigoe, Y. Tanaka, and I. Okamoto, "Binding of metal ions by pyrimidine base pairs in DNA duplexes," Chemical Society Reviews, vol. 40, no. 12, pp. 5855-5866, 2011.
[17] A. Ono, S. Cao, H. Togashi et al., "Specific interactions between silver(I) ions and cytosine-cytosine pairs in DNA duplexes," Chemical Communications, no. 39, pp. 4825-4827, 2008.

[18] D. A. Megger and J. Müller, "Silver(I)-mediated cytosine selfpairing is preferred over hoogsteen-type base pairs with the artificial nucleobase 1,3-dideaza-6-nitropurine," Nucleosides, Nucleotides and Nucleic Acids, vol. 29, no. 1, pp. 27-38, 2010.

[19] D. A. Megger, C. Fonseca Guerra, F. M. Bickelhaupt, and J. Müller, "Silver(I)-mediated Hoogsteen-type base pairs," Journal of Inorganic Biochemistry, vol. 105, no. 11, pp. 1398-1404, 2011.

[20] T. Funai, Y. Miyazaki, M. Aotani et al., " $\mathrm{Ag}^{I}$ ion mediated formation of a C-A mispair by DNA polymerases," Angewandte Chemie-International Edition, vol. 51, no. 26, pp. 6464-6466, 2012.

[21] T. Funai, J. Nakamura, Y. Miyazaki et al., "Regulated incorporation of two different metal ions into programmed sites in a duplex by DNA polymerase catalyzed primer extension," Angewandte Chemie-International Edition, vol. 53, no. 26, pp. 6624-6627, 2014.

[22] F.-A. Polonius and J. Müller, "An artificial base pair, mediated by hydrogen bonding and metal-ion binding," Angewandte Chemie-International Edition, vol. 46, no. 29, pp. 5602-5604, 2007.

[23] K. Tanaka, Y. Yamada, and M. Shionoya, "Formation of silver(I)-mediated DNA duplex and triplex through an alternative base pair of pyridine nucleobases," Journal of the American Chemical Society, vol. 124, no. 30, pp. 8802-8803, 2002.

[24] B. D. Heuberger, D. Shin, and C. Switzer, "Two Watson-Cricklike metallo base-pairs," Organic Letters, vol. 10, no. 6, pp. 10911094, 2008.

[25] I. Sinha, C. Fonseca Guerra, and J. Müller, "A highly stabilizing silver(I)-mediated base pair in parallel-stranded DNA," Angewandte Chemie-International Edition, vol. 54, pp. 3603-3606, 2015.

[26] D. A. Megger, C. Fonseca Guerra, J. Hoffmann, B. Brutschy, F. M. Bickelhaupt, and J. Müller, "Contiguous metal-mediated base pairs comprising two $\mathrm{Ag}^{\mathrm{I}}$ ions," Chemistry-A European Journal, vol. 17, no. 23, pp. 6533-6544, 2011.

[27] S. Mandal, A. Hepp, and J. Müller, "Unprecedented dinuclear silver(I)-mediated base pair involving the DNA lesion $1, N^{6}$ ethenoadenine," Dalton Transactions, vol. 44, no. 8, pp. 35403543, 2015.

[28] H. Mei, I. Röhl, and F. Seela, " $\mathrm{Ag}^{+}$-mediated DNA base pairing: extraordinarily stable pyrrolo-dC-pyrrolo-dC pairs binding two silver ions," Journal of Organic Chemistry, vol. 78, no. 18, pp. 9457-9463, 2013.

[29] H. Mei, S. A. Ingale, and F. Seela, "Imidazolo-dC metal-mediated base pairs: purine nucleosides capture two $\mathrm{Ag}^{+}$ions and form a duplex with the stability of a covalent DNA cross-link," Chemistry-A European Journal, vol. 20, no. 49, pp. 1624816257, 2014.

[30] I. Okamoto, K. Iwamoto, Y. Watanabe, Y. Miyake, and A. Ono, "Metal-ion selectivity of chemically modified uracil pairs in DNA duplexes," Angewandte Chemie-International Edition, vol. 48, pp. 1648-1651, 2009.

[31] I. Okamoto, T. Ono, R. Sameshima, and A. Ono, "Metal ionbinding properties of DNA duplexes containing thiopyrimidine base pairs," Chemical Communications, vol. 48, no. 36, pp. 43474349, 2012.

[32] J. Müller, D. Böhme, P. Lax, M. Morell Cerdà, and M. Roitzsch, "Metal ion coordination to azole nucleosides," Chemistry-A European Journal, vol. 11, no. 21, pp. 6246-6253, 2005. 
[33] S. Johannsen, N. Megger, D. Böhme, R. K. O. Sigel, and J. Müller, "Solution structure of a DNA double helix with consecutive metal-mediated base pairs," Nature Chemistry, vol. 2, no. 3, pp. 229-234, 2010.

[34] S. Kumbhar, S. Johannsen, R. K. O. Sigel, M. P. Waller, and J. Müller, "A QM/MM refinement of an experimental DNA structure with metal-mediated base pairs," Journal of Inorganic Biochemistry, vol. 127, pp. 203-210, 2013.

[35] S. Hensel, N. Megger, K. Schweizer, and J. Müller, "Second generation silver(I)-mediated imidazole base pairs," Beilstein Journal of Organic Chemistry, vol. 10, pp. 2139-2144, 2014.

[36] K. Schweizer, J. Kösters, and J. Müller, “4-(2'-Pyridyl)imidazole as an artificial nucleobase in highly stabilizing $\mathrm{Ag}(\mathrm{I})$-mediated base pairs," Journal of Biological Inorganic Chemistry, vol. 20, no. 5, pp. 895-903, 2015.

[37] K. Petrovec, B. J. Ravoo, and J. Müller, "Cooperative formation of silver(I)-mediated base pairs," Chemical Communications, vol. 48, no. 97, pp. 11844-11846, 2012.

[38] I. Sinha, J. Kösters, A. Hepp, and J. Müller, "6-Substituted purines containing thienyl or furyl substituents as artificial nucleobases for metal-mediated base pairing," Dalton Transactions, vol. 42, no. 45, pp. 16080-16089, 2013.

[39] S. M. Swasey, L. E. Leal, O. Lopez-Acevedo, J. Pavlovich, and E. G. Gwinn, "Silver (I) as DNA glue: $\mathrm{Ag}^{+}$-mediated guanine pairing revealed by removing Watson-Crick constraints," Scientific Reports, vol. 5, Article ID 10163, 2015.

[40] M. Vorlíčková, I. Kejnovská, K. Bednářová, D. Renčiuk, and J. Kypr, "Circular dichroism spectroscopy of DNA: from duplexes to quadruplexes," Chirality, vol. 24, no. 9, pp. 691-698, 2012.

[41] S. D. Solomon, M. Bahadory, A. V. Jeyarajasingam, S. A. Rutkowsky, C. Boritz, and L. Mulfinger, "Synthesis and study of silver nanoparticles," Journal of Chemical Education, vol. 84, no. 2, pp. 322-325, 2007.

[42] C. M. Ritchie, K. R. Johnsen, J. R. Kiser, Y. Antoku, R. M. Dickson, and J. T. Petty, "Ag nanocluster formation using a cytosine oligonucleotide template," Journal of Physical Chemistry C, vol. 111, no. 1, pp. 175-181, 2007. 

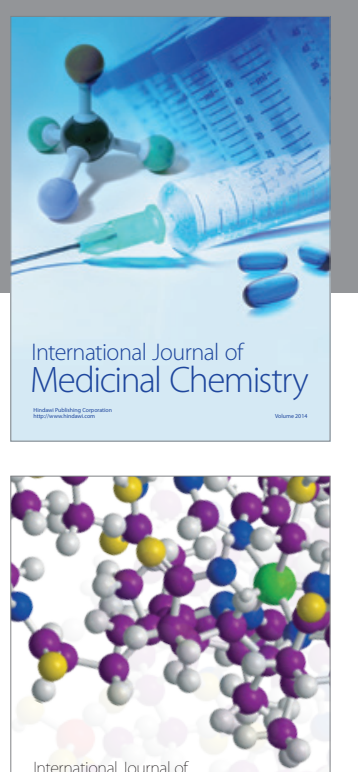

Carbohydrate Chemistry

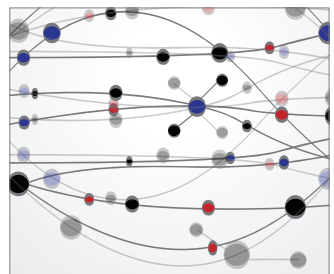

The Scientific World Journal
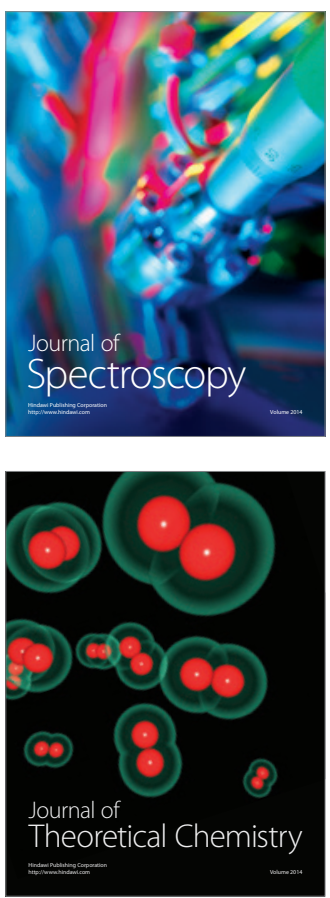
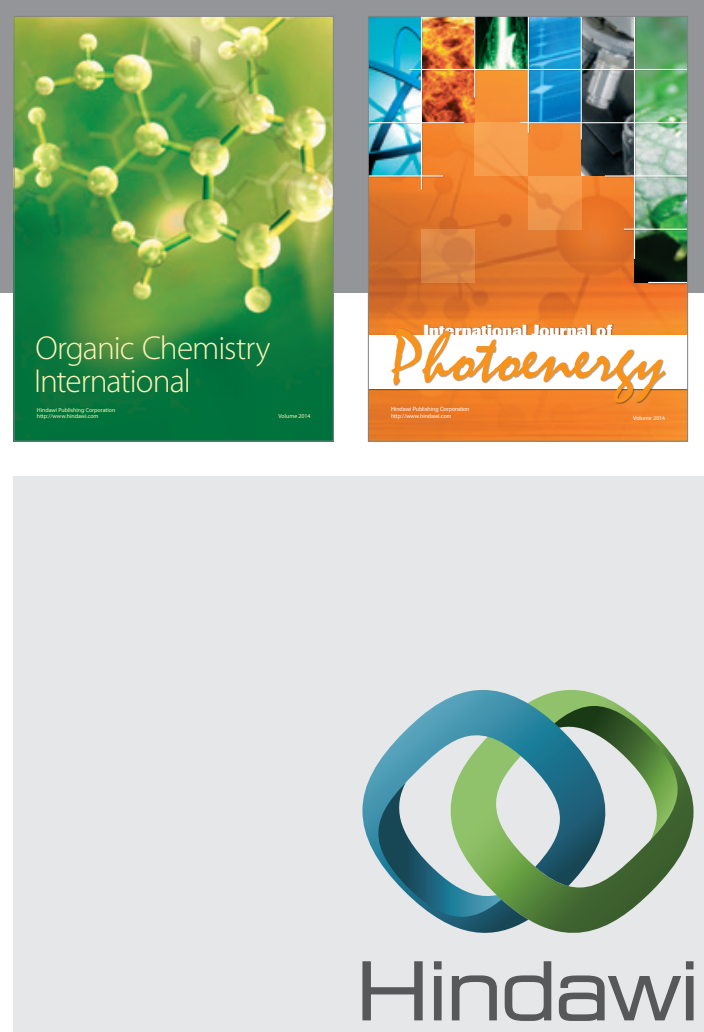

Submit your manuscripts at

http://www.hindawi.com

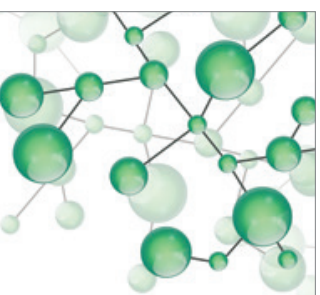

International Journal of

Inorganic Chemistry

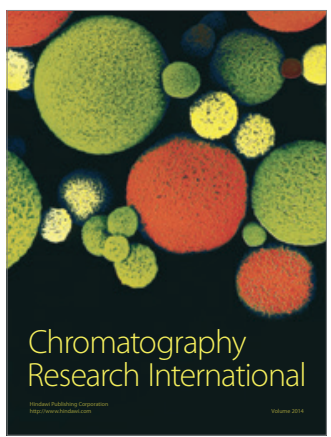

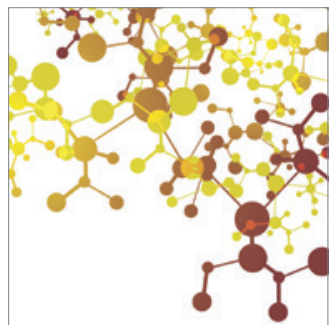

Applied Chemistry
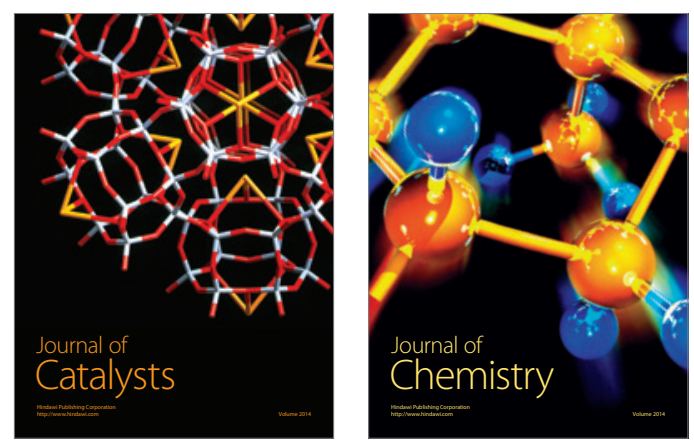
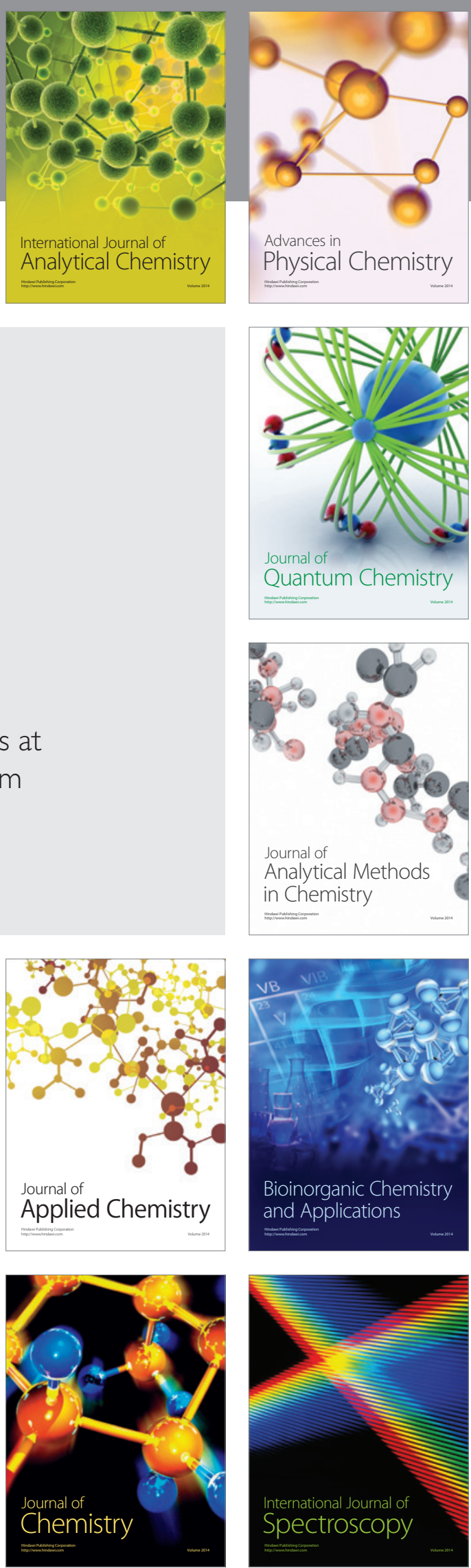